\title{
External job satisfaction factors improving the overall job satisfaction of selected five-star hotel employees
}

\author{
L. Coughlan*, H. Moolman and R. Haarhoff \\ Author 1: Department: Hotel School, Central University of Technology, Bloemfontein, South Africa \\ P.O. Box 32660, Fichardt Park, Bloemfontein, 9317 \\ lisawep@gmail.com
}

Author 2: Department: Department of Mercantile Law, University of the Free State, Bloemfontein, South Africa moolmanhj@ufs.ac.za

Author 3: Department: Tourism and Event Management, Central University of Technology, Bloemfontein, South Africa rnel@cut.ac.za

\begin{abstract}
One of the 2011 South African National Tourism Sector Strategy objectives is to "provide excellent people development and decent work within the tourism sector". The hospitality industry is, however, not regarded as a provider of decent work and a close link exists between decent work and job satisfaction. External job satisfaction can be defined as satisfaction relating to the work environment of employees. The purpose of this study was to identify the external job satisfaction factors which contribute to overall job satisfaction of employees in selected five-star hotels. The instrument used to gather the quantitative data was a newly developed index based on the literature review conducted. The empirical study was conducted among 124 employees of four five-star hotels in the Western Cape. All three factors identified (supervision, work environment and work itself) were found to be significantly and positively correlated with overall job satisfaction in five-star hotels in the Western Cape.
\end{abstract}

Keywords: External job satisfaction, five-star hotels, Western Cape

*To whom all correspondence should be addressed.

\section{Introduction}

Five-star hotels in South Africa are considered to match international standards and to denote exceptional quality (TGCSA, 2011). These hotels are therefore supposed to provide, in line with objective five of the 2011 National Tourism Sector Strategy (NTSS) (NDT, 2011:19), "a worldclass visitor experience" to its guests. Guests of five-star hotels have high service expectations and anticipate every employee at the establishment to display a friendly and helpful demeanour, willingness to assist in any situation and proactively provide information on an ongoing basis (TGCSA, 2011:25). Employee satisfaction can result in guest satisfaction (Harter, Schmidt \& Hayes, 2002:273; Vilares \& Coelho, 2003:1704) and in order for five-star hotel employees to render a world class visitor experience, the provision of decent work and job satisfaction of these employees is of great importance.

The term decent work was coined by Juan Somavia, the former Director General of the International Labour Organization (ILO), when he stated that the ILO's primary goal was "to promote opportunities for women and men to obtain decent and productive work, in conditions of freedom, equity, security and human dignity" (ILO, 2012). The ILO states that the international society is becoming progressively anxious about the lack of decent jobs and sub-
Saharan Africa shows a high risk of social unrest which influences the provision of decent work (ILO, 2012). The South African hospitality industry has been identified as a "high risk and problem sector" by the Department of Labour (BUSA, 2010:3) and is not regarded as a provider of decent work (NDT, 2011:53).

The costs of not providing decent work to employees cannot be ignored. It could negatively impact on five-star hotel employees' satisfaction, which could in turn lead to a poor visitor experience. The hotels may also lose out on the benefits of job satisfaction. These benefits include increased profit (Stanford, 2008:4; Barrows \& Powers, 2009:328), customer satisfaction (Homburg \& Stock, 2004:154; Berger \& Brownell, 2009:6), employee productivity (Harter et al., 2002:273; Saari \& Judge, 2004:398), organisational commitment (Karatepe \& Kilic, 2007:249; Lambert, Hogan \& Griffin, 2007:651; Ho, Chang, Shih \& Liang, 2009:6), employee health (Faragher, Cass \& Cooper, 2005:107; Fischer \& Sousa-Poza, 2008:389-391,393; Lee, Lee, Liao \& Chiang 2009:153), reduction in accidents (Harter et al., 2002:273; Gyekye \& Salminen, 2009:177) and lower employee turnover rates (Dawson \& Abbott, 2009:2; Hausknecht, Rodda \& Howard, 2009:282).

Occupancy rates of five-star hotels decreased from $65.8 \%$ in 2007 to $51.4 \%$ in 2011 following the 2010 Soccer World 
Cup and the global recession. These hotels are, however, recovering and the forecasted occupancy rate for 2016 is $70.5 \%$ (PwC, 2012:3, 21). The importance of providing decent work and employee job satisfaction becomes even more important in such circumstances. Limited research has been done regarding hotel employee satisfaction in South Africa. A study into external job satisfaction in five-star hotels in the Western Cape was necessary, to enable these hotels to reap the benefits associated with job satisfaction, to deliver a world-class visitor experience, and to become a provider of decent work.

\section{Literature review}

Investigations into the environment in which employees operate as well as previous researchers' findings on job satisfaction variables are important considerations as the bases of a South African hospitality job satisfaction study. An overview is provided of the South African hospitality industry and its work environment. Job satisfaction is investigated in terms of previous studies and applicable variables.

\section{The South African hospitality industry}

Tourism is one of the largest sectors in the world (NDT, 2011:4). The South African tourism sector has developed significantly since the country's first democratic election in 1994 (January-Mclean, 2010:1). Between 1993 and 2008 the number of foreign arrivals into the country has more than tripled (NDT, 2011:1). The 2012 Tourism Satellite Account for South Africa points out that tourism directly contributed $3 \%$ of the gross domestic product of South Africa in 2010 (Stats SA, 2012b:3). Tourism in South Africa is divided into five sub-sectors, namely hospitality; travel and tourism; conservation and tourism guiding; gaming and lotteries; and sport, recreation and fitness (THETA \& DEAT, 2007:9). Hospitality is the largest of these sub-sectors and also employs the largest number of employees in the tourism sector (THETA, 2010:28).

In 2005, hotels generated $63.98 \%$ of the total income generated by accommodation establishments in South Africa, with the remaining $36.02 \%$ being generated by guest houses, guest farms, caravan and camp sites and vacation homes (Stats SA, 2009:73-74). The hotel category was the largest employer in 2009, employing $61 \%$ of the total number of people employed in accommodation establishments (Stats SA, 2012a:4).

Accommodation establishments are graded from one to five stars by the Tourism Grading Council of South Africa (TGCSA). Hotels with a five-star rating are considered to match international standards and denote exceptional quality (TGCSA, 2011). The province with the most five-star hotels in South Africa is the Western Cape (TGCSA, 2011). The Western Cape was named the best destination in Africa in 2008 (De Jager, 2012), while in 2011 Cape Town was named the world's top destination at the annual TripAdvisor Travellers' Choice Awards (South African Tourism, 2011).
For these reasons, a study was warranted in this province, as the biggest opportunity to deliver a world-class visitor experience lies with five-star hotels and South Africa should aim to be at the top of travellers' wish-lists.

Employees are an important resource in the hospitality industry (Hai-yan \& Baum, 2006:509; Lee \& Way, 2010:344), and therefore also for accommodation establishments. One of the 2011 NTSS objectives is to "provide excellent people development and decent work within the tourism sector" (NDT, 2011:16). The hospitality industry's profile as a career of choice is, however, poor. Low pay, long irregular work hours and casual, part-time, seasonal or temporary employment are problems faced by hospitality employees in South Africa (CATHSSETA, 2013:18-19).

As decent work is one of government's priorities it is also important that the hospitality industry demonstrates to government that it is a provider of decent work (NDT, 2011:53). Decent work includes opportunities for work that delivers a fair income, provides security in the workplace, gives people the freedom to express their concerns, organise and participate in decisions that affect their lives and guarantees equal treatment for all (Global Unions, 2008:7). High external job satisfaction of hospitality employees can provide evidence that the hospitality industry is a provider of decent work and should therefore be of importance to all hospitality employers and managers.

\section{Job satisfaction}

There are many definitions available for job satisfaction (Locke, 1969:316; Smith, Kendall \& Hulin, 1969:7; Weiss, 2002:175; Drafke, 2009:406). Judge, Hulin and Dalal (2009:5) described job satisfactions as multidimensional psychological responses to one's job, with evaluative and emotional components. Judge et al. (2009) intentionally defined job satisfactions in the plural to include satisfaction with specific job aspects and not only overall job satisfaction (Judge et al., 2009:5). The plural job satisfaction concept makes the definition of Judge et al. (2009) unique. This study includes satisfaction with specific job aspects, as well as overall satisfaction. The definition of Judge et al. (2009) therefore aligns perfectly with the current research project. For ease of reading, however the term "job satisfaction" will be used rather than "job satisfactions" in this article.

Although an extensive number of studies have been conducted on job satisfaction (Karsh, Booske \& Sainfort, 2005; Wetprasit, 2006; Zeffane, Ibrahim \& Mehairi, 2008; Yang, 2009), limited research has been conducted on job satisfaction in the hospitality industry (Tian \& $\mathrm{Pu}$, 2008:469) and more specifically five-star hotels. Some of the studies which have been conducted on hospitality and linked with job satisfaction include Lee and Way's (2010) study on individual employment characteristics of hotel employees that play a role in employee satisfaction and worker retention, Fogaratnam and Buchanan's (2004) study 
which was based on stress of employed hospitality students and Murray-Gibbons and Gibbons' (2007) study on occupational stress in the chef profession. Birdir (2002) also conducted a study on general manager turnover in hotels and holiday villages in Turkey.

Over the years, researchers have investigated and identified many determinants of job satisfaction by use of theories, models and surveys. Drafke (2009:406-407) suggested that determinants of job satisfaction can be divided into three dimensions, namely internal, individual and external job satisfaction, each of which contains different job satisfaction variables. Internal variables are intrinsic in the work itself (Drafke, 2009:406) and include the physical work (Berger \& Brownell, 2009:304; Drafke, 2009:407) and workload (Chimanikire, Mutandwa, Gadzirayi, Muzondo \& Mutandwa, 2007:173; Ommen, Driller, Köhler, Kowalski, Ernstmann, Neumann, Steffen \& Pfaff, 2009:6). Individual variables are mainly concerned with the individual and his or her family and friends (Drafke, 2009:415). Individual variables that influence job satisfaction include emotional intelligence, as found amongst food service employees in a study conducted by Sy, Tram and O'Hara (2006:466), as well as commitment to the job (Pool \& Pool, 2007:366; Drafke, 2009:416). External variables are related to the working environment, as well as to the work itself, and are easier to change or to separate from the work itself than internal variables (Drafke, 2009:409). The authors define external job satisfaction as satisfaction relating to the work environment of employees.

Overall job satisfaction can be defined as a holistic achievement of internal, external and individual job satisfaction. The authors acknowledge the existence of internal and individual job satisfaction dimensions. This article, however, only focuses on the external job satisfaction dimension, as it is the least difficult dimension for management to alter.

A literature review was conducted to establish external job satisfaction variables that can contribute to overall job satisfaction. Trust in leadership (Bartram \& Casimir, 2007:14), support from supervisors (Chou \& Robert, 2008:220) and relationship with the supervisor (Berger \& Brownell, 2009:303) are very important in ensuring the satisfaction of employees. Berger and Brownell (2009:303) state that in the hospitality industry, company policies and procedures are important and wellness opportunities are growing in popularity to take better care of employees. Some hospitality employers are offering increased benefits, transportation and bonuses to keep employees happy (Barrows \& Powers, 2009:53).

Drafke (2009:409) stated that achievement, role ambiguity, role conflict, opportunity for advancement, job security, social interactions, relationship with co-workers, quality and fairness of supervision, management style, organisational culture, work schedules, compensation and seniority influence overall job satisfaction. In addition, tenure (Karsh et al., 2005:1277), work hours and employment status can also contribute to job satisfaction (Booth \& Van Ours,
2008:F88-89). In a hotel study conducted in America, the employee's status within the organisation, the location of the business and the department of employment contributed to job satisfaction (Lee \& Way, 2010:350-352).

In a study conducted amongst nurses, the availability of upto-date and readily available equipment was a major predictor of job satisfaction (Penz, Stewart, D'Arcy \& Morgan, 2008:797). Likewise, if the maintenance manager of a hotel does not have the equipment available to do the job properly, he or she may become frustrated and dissatisfied with the inability to successfully complete assigned tasks. The extent to which a job requires the completion of an identifiable piece of work is called task identity (Hackman \& Oldham, 1976:257). Task identity has been found to result in relaxation (Saavedra \& Kwun, 2000:142), which can have a positive effect on job satisfaction. Lastly, respondents who participated in the study of Liu and White (2011:60) commonly identified the ability to provide a social service as a determinant of their job satisfaction.

\section{Method}

Although all the above mentioned variables were found to influence job satisfaction in previous studies, there is no proof that they will influence job satisfaction in South African hotels. The methods used during the study started with determining the population. The population for the study was all levels of employees at five-star hotels in the Western Cape. Estimating the definite size of the population was practically impossible. No sampling technique was used to select hotels for this study, as all 35 five-star hotels in the Western Cape were invited to partake in the study via emails and telephone calls. The researcher personally visited hotels in the Cape Town area that had not responded to the emails and telephone calls, in an attempt to persuade more hotels to participate in the study. Ultimately, after all the researcher's efforts, four hotels agreed to participate in the research. The hotels were diverse and offered a good selection of varying environments. They were geographically widespread, with one hotel situated on a golf estate, another in the wine lands, and the other two in Cape Town itself. The hotels also varied in terms of type, with two hotels forming part of a corporate chain and the other two being independent hotels.

\section{Design and measurement instrument}

A quantitative research design was better suited to this research study than a qualitative design. Firstly, a significant amount of literature was available on potential determinants of job satisfaction. Secondly, the research focus was broad and encompassed numerous variables and finally, there was limited time available for respondents to participate in the study due to their busy work schedules (Leedy \& Ormrod, 2010:107). Therefore, a qualitative design such as personal interviews and focus group discussions were not practically possible as it would have been too time consuming. The instrument used to gather the data was a newly developed questionnaire based on the literature review conducted and 
consisted of 29 external job satisfaction variables. Refer to Table 2 for a short description of each variable.

Popular surveys used to measure job satisfaction are the JDI or Job Descriptive Index (Smith et al., 1969), on which seven variables were based (variables $4 ; 6 ; 8 ; 9 ; 10 ; 13$ and 20 in Table 2), and the Minnesota Satisfaction Questionnaire, also known as the MSQ, (Weiss, Dawis, England \& Lofquist, 1967) on which eight variables were based (variables $5 ; 6 ; 8 ; 9 ; 10 ; 20 ; 23$ and 27).

The questionnaire of Lee and Way (2010), which was recently developed specifically for use in the hospitality industry, was the bases of three variables (variables $4 ; 25$ and 26). Some variables were based on more than one existing questionnaire, some on only one and others only on the literature review conducted (variables $1 ; 2 ; 3 ; 7 ; 11 ; 12$; $14 ; 15 ; 16 ; 17 ; 18 ; 19 ; 21 ; 22 ; 24 ; 28$ and 29). The phrasing method and five-point Likert scale of the MSQ was adopted to rate the satisfaction with each of the external job satisfaction variables, where 1 equals strongly disagree (thus highly dissatisfied) and 5 strongly agree and consequently highly satisfied (Weiss et al., 1967).

The final question, i.e. "overall I am satisfied with my job", was used for statistical purposes as the dependent variable. A single-item measure of satisfaction was used since it provides a more complete picture of an employee's job satisfaction. According to Wanous, Reichers and Hudy (1997:250), the single-item measures of job satisfaction are more robust than a multiple-item scale measure of overall job satisfaction.

Following the development of the questionnaire, a pilot study was conducted at a five-star hotel in Bloemfontein, selected for the sake of convenience. The pilot study was conducted under the same conditions as the main study. Eighteen questionnaires were gathered in total. Minor adjustments were made to the questionnaire after the pilot study, and it was found that an average of 15 minutes was required for completion.

\section{Data collection}

The empirical study was conducted in February 2012. One specific day for data collection was arranged with each of the hotels who agreed to participate in the study. In each case, the researcher distributed the questionnaires to all levels of employees (part-time and full-time) working the early, late and $08 \mathrm{~h} 00$ to $17 \mathrm{~h} 00$ shifts in all departments of the hotel. Additional questionnaires were left at the hotel for employees who were busy at the time of data collection and for employees working the night shift. The researcher offered to interview illiterate employees and collected all completed questionnaires on the same day. Participating hotels also had the opportunity to return late questionnaires to the researcher, allowing all employees who had worked on the data collection day (including the night shift) an equal opportunity to participate in the study.

\section{Reliability and validity}

McMillan and Schumacher (2006:186) identified the Cronbach $\alpha$ coefficient as the best method to study the reliability of survey research when not dealing with a choice between two items, but rather a series of possible answers.

Representatives of the participating hotels were asked to approve the questionnaire prior to data collection. Their approval of the questionnaire as a measurement of employees' job satisfaction enhanced the face validity of the questionnaire (Leedy \& Ormrod, 2010:92). Since the job satisfaction questionnaire in this case was based on measurement instruments that had all already been validated, namely the MSQ (Weiss et al., 1967), JDI (Smith et al., 1969) and the questionnaire of Lee and Way (2010), the likelihood of construct validity (Bless, Higson-Smith \& Kagee, 2006:159) of the current measurement instrument was high. Although the likelihood of construct validity was high, this was uncertain in a South African context. Bless et al. (2006:157) stated that if an instrument is based on the literature of the relevant research field and the instrument measures all the different components of the variable in question, the instrument is sure to have high content validity (Babbie \& Mouton, 2008:123). The content validity of the measuring instrument in this case was proven by being founded on applicable literature and previous job satisfaction questionnaires.

Descriptive statistics, factor analysis and stepwise logistic regression analysis were used to analyse the data. Descriptive statistics in the form of frequency tables, medians and an interquartile range (IQR) for respondents were computed, since the median is a better reflection of central tendency for a skewed data set. Maximum-likelihood factor analysis was conducted to determine a factor structure. Stepwise logistic regression analysis was used to determine to what degree the factors contributed to overall job satisfaction as well as what their combined influence was.

\section{Results}

\section{Response rate}

Table 1 depicts the response rate of the employees who completed the questionnaire at each of the four hotels. Although the total response rate may appear low (33\%), this is not uncommon for hospitality-related studies. According to Keegan and Lucas $(2005: 158)$, researching in the hospitality industry is more challenging than in many other industries and low response rates are likely. 
Table 1: Response rate of hotel employees

\begin{tabular}{c|c|c|c}
\hline & $\begin{array}{c}\text { Number of } \\
\text { employees } \\
\text { onsite on } \\
\text { research day }\end{array}$ & $\begin{array}{c}\text { Returned } \\
\text { questionnaires }\end{array}$ & $\begin{array}{c}\text { Response rate } \\
\text { of employees }\end{array}$ \\
\hline Hotel A & 120 & 42 & $35 \%$ \\
\hline Hotel B & 170 & 34 & $20 \%$ \\
\hline Hotel C & 83 & 42 & $51 \%$ \\
\hline Hotel D & 7 & 6 & $86 \%$ \\
\hline Total & $\mathbf{3 8 0}$ & $\mathbf{1 2 4}$ & $\mathbf{3 3 \%}$ \\
\hline
\end{tabular}

\section{Sample profile}

A total of 124 completed questionnaires were collected from respondents at the four participating hotels. The race distribution was as follows: $37 \%$ Coloured respondents, followed closely by Africans at $33 \%$ and Whites at $28 \%$. There were only $2 \%$ Asian respondents and no other races reported.

Hospitality enterprises in South Africa are known to employ many unskilled workers (DEAT, 2005:17). This contradicts the findings of the current study, with $59 \%$ of respondents having stated high school as the highest level of qualification completed. Of the respondents, 33\% had completed a tertiary diploma and 5\% a tertiary degree. More than half $(60 \%)$ of the respondents had a hospitality-related qualification. It should be noted, however, that some of the respondents who identified high school as their highest qualification also claimed to have a hospitality-related qualification, leading to the conclusion that the "qualification" was most likely a hospitality-related school subject such as Home Economics or Hospitality Studies. Of the respondents, 39\% had no dependents and 54\% had never been married. The sample was relatively young, with $45 \%$ of respondents between the ages of 26 and 35 years and another $31 \%$ between the ages of 18 and 25 years. The sample was well balanced in terms of gender, with slightly more men $(53 \%)$ than women $(47 \%)$.

Almost half (49\%) of the respondents were working 40 to 45 hours a week on average. There were employees working more than 45 hours per week, 35\% were working between 46 and 55 hours per week and 13\% more than 55 hours per week. According to the National Department of Tourism, the South African tourism sector is known for its long working hours, as confirmed by the current research findings (NDT, 2011:53). The majority (75\%) of respondents were permanent employees. Only $12 \%$ of respondents were employed in managerial positions, with the rest of the employees (88\%) being employed in nonmanagerial positions.

\section{Main results}

Table 2 displays the main results of the study. The level of satisfaction with each external job satisfaction variable is noted as well as the median and the loadings of each item onto the factors.

Table 2: Statistical analysis (Factor solution: maximum likelihood with orthogonal rotation)

\begin{tabular}{|c|c|c|c|c|c|c|c|c|c|c|}
\hline \multirow[b]{2}{*}{ Code } & \multirow[b]{2}{*}{ Variable } & \multicolumn{5}{|c|}{ Level of satisfaction (percentage) } & \multirow[b]{2}{*}{ Median } & \multicolumn{3}{|c|}{ Factors and item loadings } \\
\hline & & 1 & 2 & 3 & 4 & 5 & & Supervision & $\begin{array}{c}\text { Work } \\
\text { Environment }\end{array}$ & Work Itself \\
\hline 1 & Role ambiguity & 2 & 2 & 2 & 56 & 38 & 4 & 0,28 & 0,18 & $0,36^{\mathrm{I}}$ \\
\hline 2 & Role conflict & 3 & 15 & 10 & 55 & 17 & 4 & $-0,03$ & 0,17 & $0,34^{1}$ \\
\hline 3 & Task identity & 3 & 3 & 3 & 61 & 30 & 4 & 0,17 & 0,08 & $0,24^{\mathrm{I}}$ \\
\hline 4 & Advancement opportunities & 7 & 13 & 20 & 44 & 16 & 4 & 0,06 & $0,54^{\mathrm{E}}$ & $-0,09$ \\
\hline 5 & Job security & 3 & 7 & 21 & 57 & 12 & 4 & $0,47^{\mathrm{s}}$ & $0,41^{\mathrm{E}}$ & $-0,02$ \\
\hline 6 & Health and safety & 7 & 10 & 9 & 53 & 21 & 4 & 0,25 & $0,67^{\mathrm{E}}$ & 0,31 \\
\hline 7 & Social interactions & 2 & 16 & 12 & 51 & 19 & 4 & 0,11 & $0,46^{\mathrm{E}}$ & 0,38 \\
\hline 8 & Relationship with co-workers & 2 & 2 & 13 & 55 & 28 & 4 & 0,14 & $0,31^{\mathrm{E}}$ & 0,05 \\
\hline 9 & Relationship with manager & 2 & 4 & 7 & 62 & 25 & 4 & $0,69^{\mathrm{S}}$ & 0,34 & 0,12 \\
\hline 10 & Quality of supervision & 2 & 6 & 10 & 63 & 19 & 4 & $0,76^{\mathrm{S}}$ & 0,22 & 0,24 \\
\hline 11 & Fairness of supervisor & 6 & 6 & 11 & 57 & 20 & 4 & $0,71^{\mathrm{s}}$ & 0,36 & 0,11 \\
\hline 12 & Manager support & 3 & 7 & 9 & 57 & 24 & 4 & $0,82^{\mathrm{S}}$ & 0,26 & 0,09 \\
\hline 13 & Participative decision making applied & 5 & 7 & 10 & 55 & 23 & 4 & $0,82^{\mathrm{S}}$ & $-0,02$ & 0,08 \\
\hline 14 & Manager adaptable & 3 & 4 & 8 & 63 & 22 & 4 & $0,72^{\mathrm{S}}$ & $-0,01$ & 0,12 \\
\hline 15 & Manager focus on staff development & 8 & 14 & 18 & 42 & 18 & 4 & $0,62^{\mathrm{S}}$ & 0,33 & 0,04 \\
\hline 16 & Trust in leadership & 2 & 8 & 5 & 57 & 28 & 4 & $0,82^{\mathrm{S}}$ & 0,2 & 0,17 \\
\hline 17 & Organisational culture & 4 & 13 & 16 & 61 & 6 & 4 & 0,38 & $0,66^{\mathrm{E}}$ & 0,22 \\
\hline 18 & Wellness opportunities & 27 & 24 & 22 & 23 & 4 & 2 & 0,05 & $0,52^{\mathrm{E}}$ & 0,25 \\
\hline 19 & Work schedule & 2 & 11 & 14 & 59 & 14 & 4 & 0,13 & 0,34 & $0,44^{\mathrm{I}}$ \\
\hline 20 & Compensation & 24 & 25 & 13 & 31 & 7 & 3 & 0,15 & $0,36^{\mathrm{E}}$ & $0,34^{I}$ \\
\hline 21 & Fringe benefits & 13 & 22 & 30 & 31 & 4 & 3 & 0,17 & $0,32^{\mathrm{E}}$ & 0,18 \\
\hline 22 & Other benefits & 24 & 21 & 30 & 22 & 3 & 3 & 0,09 & 0,21 & $0,31^{\mathrm{I}}$ \\
\hline 23 & Company policies and procedures & 9 & 17 & 28 & 41 & 5 & 3 & $0,35^{\mathrm{S}}$ & 0,31 & $0,36^{\mathrm{I}}$ \\
\hline 24 & Social service & 3 & 3 & 7 & 71 & 16 & 4 & $0,57^{\mathrm{S}}$ & 0,12 & 0,11 \\
\hline 25 & Location of the hotel & 6 & 6 & 10 & 54 & 24 & 4 & $0,54^{\mathrm{S}}$ & $-0,01$ & 0,28 \\
\hline 26 & Department of employment & 4 & 2 & 6 & 61 & 27 & 4 & $0,53^{\mathrm{s}}$ & 0,17 & 0,09 \\
\hline 27 & Achievement & 2 & 8 & 5 & 67 & 18 & 4 & $0,31^{\mathrm{S}}$ & 0,16 & 0,18 \\
\hline 28 & Availability of tools and equipment & 6 & 23 & 10 & 47 & 14 & 4 & 0,17 & $-0,13$ & $0,93^{I}$ \\
\hline 29 & Condition of tools and equipment & 10 & 21 & 12 & 46 & 11 & 4 & 0,09 & 0,04 & $0,77^{1}$ \\
\hline
\end{tabular}


It is evident from Table 2 that $56 \%$ of respondents were satisfied with their understanding of what their job entails (variable 1: role ambiguity) and a further 38\% were very satisfied. Respondents were also satisfied $(61 \%)$ and very satisfied (30\%) with task identity (variable 3$)$. With regard to department of employment (variable 26), 61\% of respondents were satisfied and $27 \%$ very satisfied with this external job satisfaction variable. Only $3 \%$ of respondents were very satisfied with the variable, other benefits (variable 22).

All the variables had a median of four, with the exception of wellness opportunities, which had a median of two, and compensation, fringe benefits, other benefits and company policies and procedures, which had medians of three. The lower quartile was the lowest for wellness opportunities, for which a lower quartile value of one was calculated. The highest upper quartile value of five was calculated for role ambiguity, task identity, relationship with co-workers, trust in leadership and department of employment. For these five variables, a median of four and an interquartile range of four to five were calculated, indicating that respondents reported the highest level of satisfaction with these variables.

A large number of respondents did not answer all the items. The missing data were imputed using LISREL's (Jöreskog \& Sörbom, 2001) matching imputation, because Likert scale data are ordinal. Not all of the data points could be imputed, but full data was obtained for 96 of the respondents.

Next, the items were analysed using maximum-likelihood factor analysis to determine any combined factors. A scree plot (Figure 1) indicated that although 11 items had eigenvalues greater than 1, a two- or three factor solution would be best.

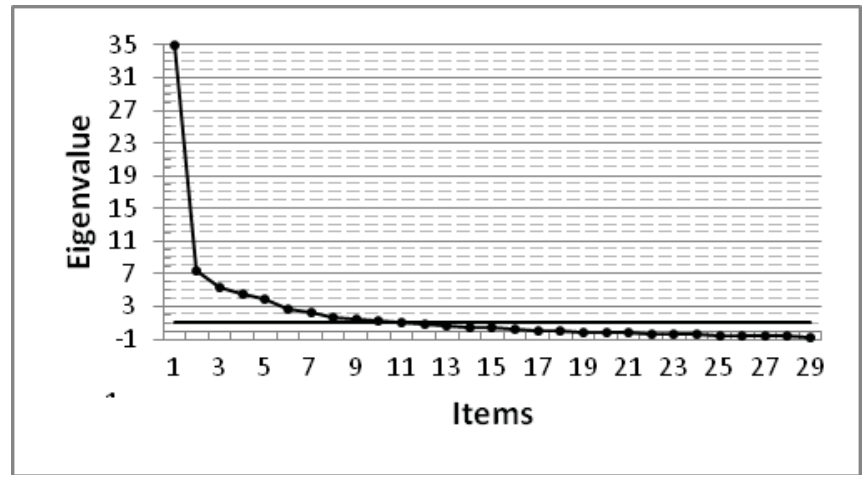

Figure 1: Maximum likelihood scree plot for 29 items

Accordingly, two- and three factor solutions were specified, but upon inspection the three factor solution presented the clearest definition of the various factors. Table 2 shows the rotated factor pattern for the three factor solution. It should be noted that not all the item loadings were ideal from the perspective of optimised convergent and discriminant validity. Ideally, each item would load on only one factor, with a loading of $>=-|.40|$, and have loadings close to zero on all other factors, but at least lower than $|.25|$ (Wille, 1996:25-26; Raubenheimer, 2004:61). Items in the range
$|.25|-|.39|$ are marked in black in Table 2, and items $>=-|.40|$ in grey. Some items showed weak loadings on all three factors (e.g. complete service). Job security showed strong loadings on more than one factor, and some items showed very similar loadings on more than one factor (e.g. income). Upon inspection of the item content, it was decided to name the three factors "Supervision", "Work Environment" and "Work Itself".

Despite the relatively minor problems in the factor structure, it was decided not to pursue further modifications (primarily because the sample of 96 was relatively small for a clean factor structure of 29 items). The factors were thus constructed of the sum of the superscripted items marked in Table 2, where each item was assigned to the factor on which it showed the strongest loading, even if that loading was relatively weak, and where items showed relatively similar loadings on more than one factor, the item was assigned to both. The three factors showed reliabilities of 0.92 for supervision (14 items), 0.80 for work environment ( 9 items), and 0.76 for work itself ( 9 items). Table 3 shows the Pearson (1896) correlations between the various factors.

Table 3: Correlation matrix for defined factors

\begin{tabular}{l|c|c}
\hline & $\begin{array}{c}\text { Work } \\
\text { Environment }\end{array}$ & Work Itself \\
\hline Supervision & $0,55^{*}$ & $0,50^{*}$ \\
\hline Work Environment & & $0,63^{*}$ \\
\hline$p^{*}<0.01$ &
\end{tabular}

Overall satisfaction, the variable of interest, was measured on three levels (Table 4), with the higher score showing greater satisfaction. It is evident that most of the respondents showed high levels of overall job satisfaction.

Table 4: Frequency distribution for overall job satisfaction

\begin{tabular}{c|c|c}
\hline $\begin{array}{c}\text { Level of } \\
\text { satisfaction }\end{array}$ & $\mathbf{N}$ & $\mathbf{\%}$ \\
\hline $\mathbf{1}$ & 14 & $14,58 \%$ \\
\hline $\mathbf{2}$ & 8 & $8,33 \%$ \\
\hline $\mathbf{3}$ & 74 & $77,08 \%$ \\
\hline
\end{tabular}

Next, Spearman (1904) correlations were calculated between these factors and the single (ordinal) item overall satisfaction, as shown in Table 5. In short, all three factors correlated significantly and positively with overall satisfaction, indicating that all three factors could act as predictors of overall job satisfaction.

Table 5: Spearman correlations between defined factors and overall job satisfaction

\begin{tabular}{l|c|c|c}
\hline & Supervision & $\begin{array}{c}\text { Work } \\
\text { Environment }\end{array}$ & Work Itself \\
\hline $\begin{array}{l}\text { Overall } \\
\text { Satisfaction }\end{array}$ & $0,32^{*}$ & $0,35^{*}$ & $0,28^{*}$ \\
\hline
\end{tabular}


The final question to be answered was to what degree the three defined factors contributed to overall satisfaction and what their combined influence was. Due to the variable of interest being ordinal, it was decided to perform a stepwise logistic regression analysis, with overall satisfaction as the criterion, and the three defined factors (supervision, work environment and work itself) as the predictors. Only one predictor (work environment) was selected. The global test for the regression analysis was significant $\left(\chi^{2}=12.48, \mathrm{df}=1\right.$, $\rho<0.01$ ), as seen in Table 6 .

Table 6: Parameter estimates for logistic regression

\begin{tabular}{l|c|c|c|c|c|c}
\hline \multicolumn{1}{c|}{ Parameter } & DF & Estimate & Standard error & $\begin{array}{c}\text { Wald Chi- } \\
\text { Square }\end{array}$ & $\begin{array}{c}\text { Pr }>\text { ChiSq } \\
\text { Odds ratio with 95\% } \\
\text { Confidence limits }\end{array}$ \\
\hline Intercept 1 & 1 & 2,85 & 1,31 & 4,76 & 0,0292 & \\
\hline Intercept 2 & 1 & 3,48 & 1,33 & 6,9 & 0,0086 & \\
\hline $\begin{array}{l}\text { Work } \\
\text { Environment }\end{array}$ & 1 & $-0,16$ & 0,05 & 12,03 & 0,0005 & $0,852|0,778| 0,933$ \\
\hline
\end{tabular}

The regression did not provide much additional information, in that the non-significance of the supervision and work itself predictors means that one cannot discern the combined influence of the various predictors on overall satisfaction, in other words the addition of more predictors does not result in a significantly better prediction of overall satisfaction.

The reason for this non-significance is to be found in the relatively strong intercorrelations between the various predictors (Table 3). This gives rise to the problem of multicollinearity (see Pedhazur, 1982:233). Essentially, there is a large proportion of shared variance between the factors in the complete regression equation for the prediction of overall satisfaction, meaning they essentially all provide the same information in this context. This, of course, is not unexpected, as one would understand that the quality of supervision would itself be a strong predictor of the quality of the work environment, as also would the work itself. In order to better predict overall satisfaction, it may be better to consider the addition of other factors related to individual and internal job satisfaction, such as satisfaction with work load and physical work.

\section{Discussion and recommendations}

This study investigated external job satisfaction in selected five-star hotels in the Western Cape. To the researchers knowledge it is the first study of its kind in the South African hospitality industry. Managers of five-star hotels can consider a number of recommendations related to external job satisfaction in an effort to improve the overall job satisfaction of employees.

\section{Supervision}

Supervisors can give all new employees a city tour and the opportunity to spend time in the different departments of the hotel; employees might then have an improved perception of the location of the hotel and be able to make informed decisions when it comes to applying for positions in other departments. Supervisors can make a deliberate effort to enhance employees' contribution in the decision making process, ensuring decent work. Being included in the decision making process also illustrates the supervisor's focus on employee development and may give the employee job security when he or she knows of the happenings in the hotel. Supervisors can encourage employees to become well acquainted with the hotel policies and procedures. Supervisors should aim to be familiar with the job, adaptive, fair, supportive and trustworthy. All of this could lead to better relationship with employees, which might result in the employees being more innovative. Employees in five-star hotels are encouraged to go the extra mile for guests. This is even of more importance when one considers that the chance to deliver a service to others could improve job satisfaction. Supervisors can create opportunities for employees to achieve service objectives in order to improve their job satisfaction.

\section{Work environment}

A healthy organisational culture has been noted as important in the pursuit of a satisfied workforce. A hotel's culture requires total involvement and commitment from top management. To ensure a healthy culture, managers could state a clearly defined purpose for the company, be realistic and adaptable, and encourage a sense of service from the employees to the hotel itself. Employees' personal needs can also be matched to a five-star hotel with a culture capable of meeting those needs. Wellness opportunities could be used to foster a healthy culture, improve co-worker relationships and give employees the chance to meaningfully interact with one another. Most five-star hotels have spa and gym facilities on site; these could be used for improved employee wellness and can also improve the health of employees.

Employees could state their career goals on appointment to be utilised to determine whether certain promotional advancements are appropriate. Several individuals want to have a career rather than just perform a job. Since job security is of importance to many employees, five-star hotels could strive to decrease the number of part-time and casual positions and could perhaps rather transfer employees between departments where they are most needed during seasonal fluctuations. Employees then have the opportunity to earn more, receive fringe benefits associated with permanent employment and enjoy decent work. 


\section{Work itself}

Role conflict can be defined as job roles interfering with one another, for example an employee is expected to complete a task, but is not given the necessary authority to do so, and should be avoided at all costs. It is difficult for an individual to be highly satisfied with the job when he or she does not know what that job entails, therefore the value and aspects of individual jobs should be explained to employees.

The availability and condition of equipment should frequently be checked and checklists to do so could be included in the policies and procedures of the hotel. Employees should be given the opportunity to deliver a complete service. This could mean that the same employee who checks the guest into the hotel can escort the guest to the room, explaining the facilities and building a relationship with the guest as they go. The additional time spent together can result in the employee being able to deliver a more individualised service to the guest, which is of utmost importance in a five-star hotel.

Due to the generally low wages paid in the hospitality industry, expenses such as childcare can be particularly stressful for employees. Day-care services offered by the employer in the form of day-care centres on or near the hotel property could have a big influence on employee satisfaction. This can serve as an addition to the employees' salaries which would lower their financial burden. Partnered with flexible work schedules, parents will be able to visit their children in conventional work hours and this may result in a more relaxed and happy work force.

Should managers implement the above mentioned strategies for improving external job satisfaction, the five-star hotels could reap the benefits associated with job satisfaction, provide excellent people development and decent work within the tourism sector, and deliver a world-class visitor experience to its guests.

\section{Limitations and directions for future research}

The results of the study should be interpreted with caution due to the limitations of the study. The results cannot be generalised with confidence to other five-star hotels in the Western Cape or South Africa. The unwillingness of the majority of five-star hotels in the Western Cape to participate in the research project as well as the employee sample size can be regarded as limitations. Employees were free to decide whether or not to participate in the study hence the absence of opinions from non-participating employees. Lastly, satisfaction can only be estimated through indicators and cannot be measured as clearly and precisely as profits (Vilares \& Coelho, 2003:1708).

There is a need for future research into five-star hotels in other provinces of South Africa, and the findings could be compared with the current research. There is also a need for job satisfaction studies in other star-rated hotels, since to the best of the researchers' knowledge; no studies of this nature have been done in South Africa. The job satisfaction levels of employees employed at different star-rated hotels could then be compared through a more heterogeneous sample. To improve the response rate in future studies the data collection period could be scheduled in the off-peak seasons of the hotels. Should data-collection be possible in both the peak and off-peak seasons, it could be determined whether the responses to questionnaires differ based on the possible changing stress levels of respondents and other changing factors.

\section{References}

Babbie, E. \& Mouton, J. 2008. The practice of social research. Cape Town: Oxford University Press.

Barrows, C.W. \& Powers, T. 2009. Introduction to management in the hospitality industry. $9^{\text {th }}$ Edition. Hoboken, NJ: John Wiley \& Sons, Inc.

Bartram, T. \& Casimir, G. 2007. 'The relationship between leadership and follower in role performance and satisfaction with the leader: The mediating effects of empowerment and trust in leadership', Leadership and Organization Development Journal, 28(1): 4-19.

Berger, F. \& Brownell, J. 2009. Organizational behavior for the hospitality industry. Upper Saddle River, NJ: Pearson Education, Inc.

Birdir, K. 2002. 'General manager turnover and root causes', International Journal of Contemporary Hospitality Management, 14(1): 43-47.

Bless, C., Higson-Smith, C. \& Kagee, A. 2006. Fundamentals of social research methods: An African perspective. $4^{\text {th }}$ Edition. Cape Town: Juta \& Co. Ltd.

Booth, A.L. \& Van Ours, J.C. 2008. 'Job satisfaction and family happiness: The part-time work puzzle', Economic Journal, 118(526): F77-F99.

BUSA (Business Unity South Africa). 2010. Parliamentary Newswatch, 2(18). Cape Town: BUSA Parliamentary Office.

CATHSSETA (Culture, Arts, Tourism, Hospitality and Sport Sector Education and Training Authority). 2013. Sector Skills Plan 2013/14 - 2015/16. Johannesburg: CATHSSETA.

Chimanikire, P., Mutandwa, E., Gadzirayi, C.T., Muzondo, N. \& Mutandwa, B. 2007. 'Factors affecting job satisfaction among academic professionals in tertiary institutions in Zimbabwe', African Journal of Business Management, 1(6): 166-175.

Chou, R.J. \& Robert, S.A. 2008. 'Workplace support, role overload, and job satisfaction of direct care workers in 
assisted living', Journal of Health and Social Behavior, 49(2): 208-222.

Dawson, M.E. \& Abbott, J. 2009. 'Hospitality culture and climate: Keys to retaining hospitality employees and creating competitive advantage'. Paper read at the International CHRIE Conference - Refereed Track. San Francisco, 29 July - 1 August 2009. Amherst: ScholarWorks@UMass, 1-8.

DEAT (Department of Environmental Affairs and Tourism). 2005. THETA Sector Skills Plan 2005 - 2009. Pretoria: Government Printer.

De Jager, P. 2012. 'Western Cape tourism and accommodation: Information Centre'. [online] URL:http://www.thewesterncape.co.za/. Accessed 2 March 2012.

Drafke, M. 2009. The human side of organizations. $10^{\text {th }}$ Edition. Upper Saddle River, NJ: Pearson Education, Inc.

Faragher, E.B., Cass, M. \& Cooper, C.L. 2005. 'The relationship between job satisfaction and health: A metaanalysis', Occupational and Environmental Medicine, 62(2): 105-112.

Fischer, J.A.V. \& Sousa-Poza, A. 2008. 'Personality, job satisfaction and health: The mediating influence of affectivity', Swiss Journal of Economics and Statistics, 144(3): 379-435.

Fogaratnam, G. \& Buchanan, P. 2004. 'Balancing the demands of school and work: Stress and employed hospitality students', International Journal of Contemporary Hospitality Management, 16(4): 237-245.

Global Unions. 2008. 'World Day for Decent Work: October 7, 2008'. [online] URL:www.globalunions.org/IMG/pdf/WDDW_brochure.en.pdf. Accessed 25 August 2012.

Gyekye, S.A. \& Salminen, S. 2009. 'Age and workers' perceptions of workplace safety: A comparative study', International Journal of Aging and Human Development, 68(2): 171-184.

Hackman, J.R. \& Oldham, G.R. 1976. 'Motivation through the design of work: Test of a theory', Organizational Behaviour and Human Performance, 16(2): 250-279.

Hai-Yan, K. \& Baum, T. 2006. 'Skills and work in the hospitality sector: The case of hotel front-office hotel employees in China', International Journal of Contemporary Hospitality Management, 18(6): 509-518.

Harter, J.K., Schmidt, F.L. \& Hayes, T.L. 2002. 'Businessunit-level relationship between employee satisfaction, employee engagement and business outcomes: A metaanalysis', Journal of Applied Psychology, 87(2): 268-279.
Hausknecht, J., Rodda, J.M. \& Howard, M.J. 2009. 'Targeted employee retention: Performance-based and jobrelated differences in reported reasons for staying', Human Resource Management, 48(2): 269-288.

Ho, W., Chang, C.S., Shih, Y. \& Liang, R. 2009. 'Effects of job rotation and role stress among nurses on job satisfaction and organizational commitment', BMC Health Services Research, 9(8): 1-10.

Homburg, C. \& Stock, R.M. 2004. 'The link between salespeople's job satisfaction and customer satisfaction in a business-to-business context: A dyadic analysis', Journal of the Academy of Marketing Science, 32(2): 144-158.

ILO (International Labour Organization). 2012. 'ILO and today's global challenges' [online] URL:http:/www.ilo.org/public/english/support/lib/century/i ndex6.htm. Accessed 14 January 2013.

ILO (International Labour Organization). 2012. 'High unemployment and growing inequality fuel social unrest around the world' [online] URL:http://www.ilo.org/global/about-the-

ilo/newsroom/news/WCMS_179430/lang--en/index.htm. Accessed 23 April 2013.

January-Mclean, T. 2010. Presentation by Ambassador Thandiwe January-Mclean, chief executive officer, South African Tourism. Tourism Summit 2010. Port Elizabeth, 15 April 2010.

Jöreskog, K.G. \& Sörbom, D. 2001. 'LISREL 8.5 for Windows'. Skokie, IL: Scientific Software International, Inc. [Computer Software] [online] URL:www.ssicentral.com.

Judge, T.A., Hulin, C.L. \& Dalal, R.S. 2009. 'Job satisfaction and job affect'. In: Kozlowski, S.W.J. (ed.). Oxford handbook of industrial and organizational psychology. New York, NY: Oxford University Press.

Karatepe, O.M. \& Kilic, H. 2007. 'Relationships of supervisor support and conflicts in the work-family interface with the selected outcomes of front-line employees', Tourism Management, 28(1): 238-252.

Karsh, B., Booske, B.C. \& Sainfort, F. 2005. 'Job and organizational determinants of nursing home employee commitment, job satisfaction and intent to turnover', Ergonomics, 48(10): 1260-1281.

Keegan, S.N. \& Lucas, R. 2005. 'Hospitality to hostility: Dealing with low response rates in postal surveys', Hospitality Management, 24(2): 157-169.

Lambert, E.G., Hogan, N.L. \& Griffin, M.L. 2007. 'The impact of distributive and procedural justice on correctional staff job stress, job satisfaction and organizational commitment', Journal of Criminal Justice, 35(6): 644-656. 
Lee, C. \& Way, K. 2010. 'Individual employment characteristics of hotel employees that play a role in employee satisfaction and work retention', International Journal of Hospitality Management, 29(3): 344-353.

Lee, M.S., Lee, M., Liao, S. \& Chiang, F. 2009. 'Relationship between mental health and job satisfaction among employees in a medical centre department of laboratory medicine', Journal of the Formosan Medical Association, 108(2): 146-154.

Leedy, P.D. \& Ormrod, J.E. 2010. Practical research: Planning and design. $9^{\text {th }}$ Edition. Upper Saddle River, NJ: Pearson Education.

Liu, C.S. \& White, L. 2011. 'Key determinants of hospital pharmacy staff's job satisfaction', Research in Social and Administrative Pharmacy, 7(1): 51-63.

Locke, E.A. 1969. 'What is job satisfaction?' Organizational Behavior and Human Performance, 4(4): 309-336.

McMillan, J. \& Schumacher, S. 2006. Research in education: Evidence based enquiry. $6^{\text {th }}$ Edition. Upper Saddle River, NJ: Pearson Education, Inc.

Murray-Gibbons, R. \& Gibbons, C. 2007. 'Occupational stress in the chef profession', International Journal of Contemporary Hospitality Management, 19(1): 32-42.

NDT (National Department of Tourism). 2011. National tourism sector strategy February 2011 - Embargoed. Pretoria: Government Printer.

Ommen, O., Driller, E., Köhler, T., Kowalski, C., Ernstmann, N., Neumann, M., Steffen, P. \& Pfaff, H. 2009. 'The relationship between social capital in hospitals and physician job satisfaction', BMC Health Services Research, 9(81): $1-9$.

Pearson, K. 1896. 'Mathematical contributions to the theory of evolution. III. Regression, heredity and panmixia', Philosophical Transactions of the Royal Society of London, 187: 253-318.

Pedhazur, J.E. 1982. Multiple regression in behavioral research. Fort Worth: Holt, Rinehart and Winston.

Penz, K., Stewart, N.J., D’Arcy, C. \& Morgan, D. 2008. 'Predictors of job satisfaction for rural acute care registered nurses in Canada', Western Journal of Nursing Research, 30(7): 785-800.

Pool, S. \& Pool, B. 2007. 'A management development model', Journal of Management Development, 26(4): 353369.

PwC (PricewaterhouseCoopers). 2012. South African hospitality outlook: 2012-2016. Johannesburg: PwC.
Raubenheimer, J. 2004. 'An item selection procedure to maximise scale reliability and validity', SA Journal of Industrial Psychology, 30(4): 59-64.

Saari, L.M. \& Judge, T.A. 2004. 'Employee attitudes and job satisfaction', Human Resource Management, 43(4): 395407.

Saavedra, R. \& Kwun, S.K. 2000. 'Affective states in job characteristics theory', Journal of Organizational Behavior, 21(2): 131-146.

Smith, P.C., Kendall, L.M. \& Hulin, C.L. 1969. The measurement of satisfaction in work and retirement. Chicago, IL: Rand McNally.

South African Tourism. 2011. 'TripAdvisor name Cape Town world's top destination'. [online] URL:http://www.southafrica.net/sat/content/en/za/businesstourism-news-

detail?oid $=389339 \&$ sn=Detail\&pid=259797\& TripAdvisornames-Cape-Town-world-s-top-destination. Accessed 5 September 2012.

Spearman, C. 1904. 'The proof of measurement of association between two things', American Journal of Psychology, 15(1): 72-101.

Stanford, D. 2008. 'Examining the relationship between job satisfaction and customer satisfaction in a South African firm'. Unpublished MBA thesis University of Pretoria, Pretoria.

STATS SA (Statistics South Africa). 2009. Draft tourism satellite account for South Africa, 2005. Pretoria: Statistics South Africa.

STATS SA (Statistics South Africa). 2012a. Accommodation industry, 2009 (Preliminary). Pretoria: Statistics South Africa.

STATS SA (Statistics South Africa). 2012b. Tourism satellite account for South Africa, 2012 (Provisional). Pretoria: Statistics South Africa.

Sy, T., Tram, S. \& O'Hara, L.A. 2006. 'Relation of employee and manager emotional intelligence to job satisfaction and performance', Journal of Vocational Behavior, 68(3): 461-473.

TGCSA (Tourism Grading Council of South Africa). 2011. What is star grading? Johannesburg: TGCSA.

THETA (Tourism, Hospitality and Sport Education Training Authority). 2010. Sector skills plan 2011/12 - 2015/16: $1^{\text {st }}$ Draft submission - 30 September 2010. Pretoria: Government Printer.

THETA \& DEAT (Tourism, Hospitality and Sport Education Training Authority \& Department of External 
Affairs and Tourism). 2007. Skills in tourism and sport: Emerging themes, 2007. Pretoria: Government Printer.

Tian, X. \& Pu, Y. 2008. 'An artificial neural network approach to hotel employee satisfaction: The case of China', Social Behaviour and Personality, 36(4): 467-482.

Vilares, M.J. \& Coelho, P.S. 2003. 'The employee-customer satisfaction chain in the ECSI model', European Journal of Marketing, 37(11/12): 1703-1722.

Wanous, J.P., Reichers, A.E. \& Hudy, M.J. 1997. 'Overall job satisfaction: How good are single-item measures', Journal of Applied Psychology, 82(2): 247-252.

Weiss, H.M. 2002. 'Deconstructing job satisfaction: Separating evaluations, beliefs and affective experiences', Human Resource Management Review, 12(2): 173-194.

Weiss, D.J., Dawis, R.V., England, G.W. \& Lofquist, L.H. 1967. Manual for the Minnesota Satisfaction Questionnaire. Minneapolis, MN: University of Minnesota.

Wetprasit, P. 2006. 'Impacts of work-related determinants on job satisfaction and retention intentions in Thai spa industry'. PhD thesis Oklahoma State University, Stillwater, Oklahoma.

Wille, G.W. 1996. 'A stepwise procedure for the empirical assessment of latent variable models.' Unpublished Master's thesis, University of Port Elizabeth, Port Elizabeth.

Yang, Y. 2009. 'investigation of group interaction functioning stimulated by transformational leadership on employee intrinsic and extrinsic job satisfaction: An extension of the resource-based theory perspective', Social Behavior and Personality, 37(9): 1259-1278.

Zeffane, R., Ibrahim, M.E. \& Mehari, R.A. 2008. 'Exploring the differential impact of job satisfaction on employee attendance and conduct: The case of a utility company in the United Arab Emirates', Employee Relations, 30(3): 237-250. 